\title{
Assessment of Day Caring Methods among Civil Servant Mothers of Reproductive Age in Lagos State Nigeria
}

\author{
Caroline Funmbi Akinnubi ${ }^{1, *}$ \\ ${ }^{1}$ Department of Physical and Health Education, Obafemi Awolowo University, Ile-Ife, Osun State, Nigeria \\ *Correspondence: Department of Physical and Health Education, Obafemi Awolowo University, Ile-Ife, Osun State, \\ Nigeria. Tel: 234-703-116-4469. E-mail: fakinnubi@yahoo.com
}

Received: January 19, 2016

Accepted: March 7, $2016 \quad$ Online Published: May 18, 2016

doi:10.5430/wje.v6n3p21

URL: http://dx.doi.org/10.5430/wje.v6n3p21

\begin{abstract}
This study examined the day caring methods among the civil servants of reproductive age with children between three months to four years in Lagos State Nigeria. The research design employed for this study was a descriptive research design. A total number of 212 teachers and 128 ministry workers making a total of 340 reproductive age mothers were purposively selected from the State. A self-structured questionnaire was used to collect information from the respondents. Accidental sampling technique was adapted to survey the respondents for this study. Data were analyzed using frequency distribution, simple percentages and inferential statistic of t-test analysis. The results of the study revealed that $30(8.8 \%)$ teachers and $33(9.7 \%)$ ministry workers agreed that they kept their child/children in crèche. The study showed that $188(55.3 \%)$ teachers and $92(27 \%)$ ministry workers agreed that they wanted to have time to care for themselves, while $204(60 \%)$ teachers and $38(11.2 \%)$ ministry workers agreed that they liked to get back to their work and be efficient. It was also revealed that a reasonable proportion of the teachers agreed that there were adequate personnel and adequate rooms for learning, while the ministry workers disagreed. The results further showed that many of the day care workers were not well educated. Based on the findings, it is recommended that the civil servants should be educated on the need to adopt the modern and educative methods of day care.
\end{abstract}

Keywords: day caring; methods; civil servants; teachers; ministry workers; mothers; reproductive age

\section{Introduction}

Day caring method among the civil servants mothers is an aspect of life which these reproductive age mothers should be mindful of. This stage is so complex that the civil servants need to critically observe, in that it deals with the lives of both the mother and the child. Day care is an environment which is organized, managed and controlled by organization, agency or an individual for the caring of children during the day. Reproductive age among women is a period when they are fertile and are able to give birth to young ones. According to Read (2001), day care is an environment where little children learn as they share experiences with their peer group. It is a place where personnel in the day care centres provide variety of resources and learning experiences necessary for the needs of individual child, guidance and encouragement are usually offered for the children for effectively learning.

According to Adetunji (2002), childhood education is mostly saddled with establishing pre-school that prepare children for formal schooling that are often called Nursery school, kindergarten, daycare etc. There is presently a progressive demand for day caring from salary earning segment, this concerns the working parents or the guardians (Caldwell 2001). Child care, child minding daycare or preschool is the caring and monitoring of a child or children. It is the act of taking care of child or children by a day-care centre, babysitter, or other providers. (https://en.wikipedia.org/wiki/child_care). Day care is the care usually given to infants, toddlers, preschoolers, and school-aged children, in their own homes, home of a relative, other caregiver or in a centre-based facility (http://ww.healthof children.com/D/Day-care.html).

Childcare is of two types; registered formal childcare and informal childcare. Registered childcare is said to be registered with the necessary governing body of devolved administrations (Campbell-Barr and Garnham 2010). Iversen and Annie (2006) reported that despite the long and uneven working hours which comprise evening and 
weekends, poor parents are more likely to utilize informal childcare. There are two types of day care centers which are used by working parents; they are regulated and unregulated daycare centers. Regulated daycare centers requires a license from the government to operate, while unregulated daycare are those that did not meet the approved standard (not licensed) but should meet the minimum approved standards (http:www.yellowpage.ca/what-are-the-different-types-of-daycare).

The two major types of child care options for employed parents are; centered-based care (creche, daycare, preschools,) and home-based care (nanny or family daycare) (http://www.childforum.com/options-a-differences-between-ece-). Preschool care centre is usually attributed to child care centre that care mainly for 4-year old and below children. Preschool day care can be built and operated in centre, such as family child care, in-home or a public school (Office of Head Starthttp://www.acf.hhs.gov/programs/ohs/about/index.html\#prog_desc). In-home care is said to be operated in the child's own home (/knowledge /Occupational_safety_and_health.html). The child is overseen inside their own home or the caregiver's home, thereby minimizing the exposure to outside children and illnesses (https://en.wikipedia.org/wiki/child_care).

A nanny or au pair is not always the best methods of childcare, because it is the most expensive form of childcare. Recruiting a nanny can be costly when using a nanny agency. Nanny care confines the child into a world of their own, thereby debarring them from interacting with children from other many a times (http:/!nannycity.com/checking-nanny-references/). Commercial care centres are day cares with a formulated standard and regulated system of caring for children, generally opened for set hours, Parents usually use commercial care centre nearer to their place of work. Active children usually succeed in the educational activities such as engaging in academic achievement, gain independence and are able to socialize with others (http://www.pregnancy.org /article/daycare-vs-nanny). Children from low quality centres may not achieve as expected in vocabulary and reading skills (http://singlemotherguide.com/cost-of-child-care/).

Informal childcare do utilizes family members as a childcare system, examples are grandparents and siblings. It is specifically used by parents who are poor and unable to fund for their children in an expensive child care, therefore the informal childcare is termed to be not expensive (Schonpflug, Karin, Feminism, Economics and Utopia: 2008). Poverty restricts many mothers of school-age children to low-paid work within school hours (Butt et al., 2007, Campbell-Barr, 2010a). The parental decisions of who to leave a child with and who that person usually create problem in the lives of most parents (Cohn 2013). Children in centre-based care regularly display improved cognitive development than those cared for in homes, because of more opportunities they have, they have the tendency to learn more with materials (/C/Cognitive-Development.html). Learning stories are documents used by careers and educators in childcare settings. These are used as a format than a traditional observation to document various ways children can learn (Carr 2012).

The parents look for good qualities in day care centers which can influence their child/children positively, such as well qualified, trained or experienced staff' ( 74 per cent); warm and caring atmosphere' (59 per cent); Good Ofsted report' (44 per cent), and cost' (36 per cent) (Daycare Trust 2010). According to Mori (2004), research had revealed that parents did rate good staff, warm and caring atmosphere, good quality of buildings, health and safety as priorities for their children, while Sylva, Melhuius, Sammons, Saraj-Baltchford, Taggart (2004), said that children in pre-school centres make more progress when staff and the administrators are well qualified. Melhuish (2004), connoted that factors associated with staff distinctiveness quality are higher level of staff education, in-service training, staff experienced in working with children, low staff turnover, satisfactory staff pay; and a trained centre manager to offer staff support and supervision.

Good quality and available child care help the parents to work effectively well, to be self satisfactory in their place of work, and also meet their family needs (U.S. Census Bureau 2008). Employers could fund child care solely for their employees for effective turnover of their workers (Warner, Anderson, and Haddow 2007). Adequate furnishing materials and equipment are important components of good quality child care, which the providers and licensing officers needed (Furnishings \& Equipment Guidelines).

\section{The Problem of the Study}

Lagos state is a very big city in Nigeria. It was formally the federal capital of Nigeria before the federal capital was moved to Abuja. So parents' particularly civil servants in Lagos State are found of leaving their homes very early in the morning to their places of work because of distance and traffic problem. As a result of this, they do leave their children in the hands of their house girl, local day care around the environment, take them to their place of work, or 
the nanny. These parents use the aforementioned type of day caring methods because they are not aware of the importance of modern and educative methods of day care. These children are the future of tomorrow. They need to be safe guided for adequate training and educational background they needed, so as to make them responsible to themselves and to the society at large, hence this study.

\section{The Aim of the Study}

The aim of this paper is to assess and identify the day caring methods, reasons for keeping child/ children in day care centers, day care center workers qualifications and the adequacy of equipment/facilities and instructional materials so also have qualitative education, because they are the future of tomorrow. Therefore the following research questions leading to hypotheses were raised:

\section{Importance of the Study}

The study will make parents of reproductive age to be aware of importance of modern and qualitative education. It will also make the parents to give their children modern and qualitative education.

\section{Research Questions}

1. Which of the day caring methods do the civil servants of reproductive age adopt in rearing their children in Lagos State?

2. Why do civil servants keep your child/children in the day care centres?

3. What qualifications do your day care workers have?

4. Are there adequate facilities/equipment and instructional materials for children use in the day care centres in Lagos State?

\section{Research Hypothesis}

a. There will be no significant difference in the qualifications of the day care centre workers where civil servants keep your child/children by location (teachers and civil servants).

b. There will be no significant difference in the adequate facilities/equipment and instructional materials for children use in the day care centres' by location (teachers and civil servants).

\section{Methods and Procedures}

\subsection{Research Design}

This study employed the descriptive survey design. This type of research design was considered appropriate because it does not submit to variables(s) manipulation but described the existing situation regarding the day caring practices as it is.

\subsection{The Population and Sampling Technique}

The population of the study consisted of all civil servants with child/children between 3 months to four years in Lagos state. The sampled population was reproductive age mothers of 212 teachers in secondary schools and 128 ministry workers making a total of 340 respondents were purposively selected in Lagos State. Accidental sampling technique was adopted to survey the respondents for this study.

\subsection{The Instrument of the Study}

A self-structured questionnaire was used to collect data for the study. The questionnaire tagged (DCMQ) contained two sections, A and B. Section A of the questionnaire dealt with the demographic characteristics of subject (i.e the age, and profession) and section B consisted of four sections, which was designed to elicit information regarding methods adopted, the adequacy of the instructional materials used, the personnel qualifications and reasons for keeping the child in the day care centers. The instrument was validated by two experts in the department, their corrections and suggestions were used to prepare the final draft of the questionnaires. The test retest method was adopted to test reliability using Pearson product moment correlation coefficient of 0.83 which was deemed high and reliable at 0.05 alpha level of significant level. The questionnaires were administered directly on 340 respondents by the researcher and six research assistants to elicit information for the data collection. The questionnaires were immediately collected. 
The data collected were analyzed using frequency distribution, simple percentages and inferential statistics of t-test.

\section{Results and Discussion}

\subsection{Data Analysis and Presentation of Results}

Table 1. Frequency Distribution and Percentages of Respondents by Occupation and Age Range

\begin{tabular}{llllllllll}
\hline S/N & Variable & Below & $31-35$ & $36-40$ & $41-45$ & $46-50$ & $51-55$ & $56-60$ & Total \\
& & 30 years\% & years \% & Years \% & Years \% & Years \% & Years \% & Years \% & $\%$ \\
\hline 1. & Teachers & $33(9.7)$ & $33(9.7)$ & $29(8.5)$ & $36(10.6)$ & $44(12.9)$ & $25(7.4)$ & $12(3.6)$ & $212(62.4)$ \\
2. & $\begin{array}{l}\text { Ministry } \\
\text { Workers }\end{array}$ & $19(5.6)$ & $22(6.5)$ & $34(10)$ & $22(6.5)$ & $21(6.2)$ & $06(1.8)$ & $04(1.2)$ & $128(37.6)$ \\
& & & & & & & & \\
& Total & $52(15.3)$ & $55(16.2)$ & $63(18.5)$ & $58(17.1)$ & $65(19.1)$ & $31(9.1)$ & $16(4.7)$ & $340(100)$ \\
\hline
\end{tabular}

\subsection{Research Question 1:}

Which of the day caring methods do the civil servants adopted in rearing their children in Lagos State

Table 2. Descriptive Analysis of Day Caring Methods Adopted by Civil Servants

\begin{tabular}{|c|c|c|c|c|c|}
\hline \multirow[t]{3}{*}{$\mathrm{S} / \mathrm{N}$} & \multirow[t]{3}{*}{ Determinants } & \multicolumn{4}{|c|}{ Respondents } \\
\hline & & \multicolumn{2}{|c|}{ Teachers 212} & \multicolumn{2}{|c|}{ Ministry Workers 128} \\
\hline & & Agreed \% & Disagreed \% & Agreed \% & Disagreed \% \\
\hline 1. & Keeping the child with the grand mother & $22(6.5 \%)$ & $190(55.9 \%)$ & $14(4.1 \%)$ & $114(33.5 \%)$ \\
\hline 2. & $\begin{array}{l}\text { Keeping the child with the local day care } \\
\text { around the environment. }\end{array}$ & $36(10.6 \%)$ & $176(51.8 \%)$ & $42(12.4 \%)$ & $86(25.3 \%)$ \\
\hline 3. & Taking the child to place of work & $30(8.8 \%)$ & $182(53.5 \%)$ & $22(6.5 \%)$ & $106(31.2 \%)$ \\
\hline 4. & $\begin{array}{l}\text { Keeping the child in the crèche with the grand } \\
\text { mother }\end{array}$ & $30(8.8 \%)$ & $182(53.5 \%)$ & $33(9.7 \%)$ & $95(28 \%)$ \\
\hline 5. & Keeping the child in the nursery school & $34(10 \%)$ & $188(55.3 \%)$ & $18(5.3 \%)$ & $110(32.4 \%)$ \\
\hline 6. & Keeping the child with the house girl at home & $41(12.1 \%)$ & $171(50.3 \%)$ & $09(2.6 \%)$ & $119(35 \%)$ \\
\hline 7. & Keeping the child with the nanny & $25(7.4 \%)$ & $187(55 \%)$ & $12(3.5 \%)$ & $116(34.1 \%)$ \\
\hline
\end{tabular}

Table 2 above showed that a total of $22(6.5 \%)$ teachers and 14(4.1\%) ministry workers making a total of $36(10.6 \%)$ agreed to keeping the child with the grandmother. A total of $30(8.8 \%)$ teachers and $33(9.7 \%)$ ministry workers making a total of $66(18.5 \%)$ agreed to keeping the child in crèche. As regards to keeping the child in the nursery school, a total of $34(10 \%)$ teachers and $18(5.3 \%)$ ministry workers making a total of $52(15.3 \%)$ agreed with this statement. The findings of this table 2 showed that both the teachers and the ministry workers did not use the modern and educative methods of child care (crèche and nursery school) where children can learn effectively well. This is in agreement with (http://singlemotherguide.com/cost-of-child-care/) that children from low quality centres may not achieve as expected in terms of vocabulary and reading skills, but not in line with (/C/Cognitive-Development.html) which stated that children in centre-based care usually display improved cognitive development than those cared for in-homes, because of more opportunities they have, so they have tendency to learn more with materials, and U.S. Census Bureau (2008), which connoted that good quality and available child care help the parents to work effectively well in their work, be self satisfactory and also meet their family needs.

\subsection{Research Question 2:}

Why do you keep your child/children in the day care centres 
Table 3. Descriptive Analysis of Reasons for Keeping Child/Children in the Day Care Centres

\begin{tabular}{|c|c|c|c|c|c|}
\hline \multirow[t]{3}{*}{$\mathrm{S} / \mathrm{N}$} & \multirow[t]{3}{*}{ Determinants } & \multicolumn{4}{|c|}{ Respondents } \\
\hline & & \multicolumn{2}{|c|}{ Teachers 212} & \multicolumn{2}{|c|}{ Ministry Workers 128} \\
\hline & & Agreed $\%$ & Disagreed\% & Agreed $\%$ & Disagreed $\%$ \\
\hline 1. & I want to have time to care for myself & $188(55.3 \%)$ & $24(7.1 \%)$ & $92(27 \%)$ & $36(10.6 \%)$ \\
\hline 2. & I am a pregnant mother & $30(8.8 \%)$ & $182(53.5 \%)$ & $12(3.5 \%)$ & $116(34.2 \%)$ \\
\hline 3. & $\begin{array}{l}\text { My child needs the company of other } \\
\text { children. }\end{array}$ & $49(14.4 \%)$ & $163(47.9 \%)$ & $80(23.5 \%)$ & $48(14.1 \%)$ \\
\hline 4. & My child is troublesome and will disturb me. & $104(30.6 \%)$ & $10(31.8 \%)$ & $23(6.8 \%)$ & $105(30.9 \%)$ \\
\hline 5. & I am a civil servant. & $189(55.6 \%)$ & $23(6.8 \%)$ & $118(34.7 \%)$ & $10(2.9 \%)$ \\
\hline 6. & $\begin{array}{l}\text { I like to get to my place of work and be } \\
\text { efficient. }\end{array}$ & $204(60 \%)$ & $08(2.3 \%)$ & $38(11.2 \%)$ & $90(26.5 \%)$ \\
\hline
\end{tabular}

Table 3 above shows that a total of $188(55.3 \%)$ teachers and $92(27 \%)$ ministry workers agreed that they wanted to have time to care for themselves, while a total of $104(30.6 \%)$ teachers and 23(6.8\%) ministry workers agreed that their children were so active and troublesome and could disturbed them. As regards being a civil servant, a total of $189(55.6 \%)$ teachers and $118(34.7 \%)$ ministry workers agreed to this statement, while a total of $204(60 \%)$ teachers and $38(11.2 \%)$ ministry workers agreed that they liked to get to their place of work and be efficient. This implied that many of respondents sent their children to day care because they wanted to have time for themselves, and be efficient at their place of work. This finding of this study supports U.S. Census Bureau (2008), which reported that good quality and available child care help the parents to work effectively well in their work, be self satisfactory and also meet their family needs, and Warner, Anderson, and Haddow. (2007), that employers could fund child care solely for their employees for effective turnover of their workers.

\subsection{Research Question 3:}

What qualifications do the day care centre workers where you keep your child/children have?

Table 4. Descriptive Analysis of Qualifications of the Day Care Centre Workers

\begin{tabular}{llllll}
\hline S/N & Determinants & \multicolumn{3}{l}{ Respondents } & \\
\cline { 3 - 5 } & & \multicolumn{2}{l}{ Teachers 212 } & & Ministry Workers 128 \\
\cline { 3 - 6 } & & Agreed $\%$ & Disagreed $\%$ & Agreed \% & Disagreed \% \\
\hline 1. & Illiterate & $18(5.3 \%)$ & $194(57.1 \%)$ & $14(4.1 \%)$ & $114(33.5 \%)$ \\
2. & Primary six certificate & $16(4.7 \%)$ & $196(57.6 \%)$ & $18(5.3 \%)$ & $110(32.4 \%)$ \\
3. & Junior Secondary School Certificate & $36(10.8 \%)$ & $176(51.8 \%)$ & $22(6.5 \%)$ & $106(31.1 \%)$ \\
4. & Senior Secondary School Certificate & $44(12.9 \%)$ & $168(49.4 \%)$ & $16(4.7 \%)$ & $112(32.9 \%)$ \\
5. & OND Certificate & $34(10 \%)$ & $178(52.4 \%)$ & $11(3.2 \%)$ & $117(34.4 \%)$ \\
6. & HND Certificate & $20(5.8 \%)$ & $192(56.5 \%)$ & $15(4.5 \%)$ & $113(33.2 \%)$ \\
7. & National Certificate of Education & $24(7.1 \%)$ & $188(55.3 \%)$ & $20(5.9 \%)$ & $108(31.7 \%)$ \\
8. & University Graduate & $20(5.9 \%)$ & $192(56.5 \%)$ & $12(3.5 \%)$ & $106(31.1 \%)$ \\
\hline
\end{tabular}

Table 4 above shows that a total of $18(5.3 \%)$ teachers and $14(4.1 \%)$ ministry workers said that the day care centre workers where you kept your child/children were illiterates, while $44(12.9 \%)$ teachers and $16(4.7 \%)$ ministry workers agreed that the day care centre workers where you kept your child/children were senior secondary school Certificate holder. A total of 20(5.9\%) teachers and 12 (3.5\%) ministry workers said that the day care centre workers where you kept your child/children were university Graduates. The above indicated that very many of the workers/personnel were not well educated. This contradicts Daycare Trust (2010) affirmation that parents look for good qualities in day care centers which can influence their child/children positively, such qualities could be well qualified, trained or experienced staff, Mori (2004), who revealed that parents did rate good staff as priority for their children, and Sylva et al., (2004), who said that children in pre-school centres make more progress when staff had higher qualifications and the administrators are equally well qualified. 


\section{5}

Table 5. T-Test of Difference between the Mean Scores in the Qualifications of the Day Care Centre Workers Where Civil Servants Keep Your Child/Children

\begin{tabular}{llllllll}
\hline Civil servants & N & mean & std & df & t-cal & t-critical & Decision \\
\hline Teachers & 212 & 11.346 & 1.873 & 121 & 2.143 & 1.640 & $\mathrm{~S}$ \\
Ministry workers & 128 & 11.382 & 1.865 & & & & \\
$\mathbf{P}<\mathbf{0 . 0 5}$ & & & & & & &
\end{tabular}

The result of the above table 5reveals that the t-calculated value (2.143) which was greater than the t-critic (1.640), $(\mathrm{t}-\mathrm{cal}=2.143$, $\mathrm{t}$-critic $=1.640, \mathrm{P}<0.05)$. Therefore the null hypothesis was rejected. There was a significant difference in the qualifications of the day care centre workers where civil servants keep your child/children by location (teachers and civil servants). This implied that, despite the respondents from the two locations identified that many of the day care centre workers were educated, but their qualifications were not similar.

8.6 Research Question 4: Are there adequate facilities/equipment and instructional materials for children use in the day care centres'.

Table 6. Descriptive Analysis of Adequacy of Facilities/Equipment and Instructional Materials/Instructions for Children Use in the Day Care Centres

\begin{tabular}{llllll}
\hline S/N Determinants & \multicolumn{3}{c}{ Respondents } \\
\cline { 3 - 6 } & & \multicolumn{2}{c}{ Teachers 212 } & Ministry Workers 128 \\
\cline { 3 - 5 } & & Agreed $\%$ & Disagreed \% & Agreed \% & Disagreed \% \\
\hline 1. & Adequate Toys & $85(25 \%)$ & $127(37.4 \%)$ & $24(7.1 \%)$ & $104(30 \%)$ \\
2. & $\begin{array}{l}\text { Adequate Instructional materials such as } \\
\text { educational motion picture, or model, }\end{array}$ & $102(29.4 \%)$ & $110(32.4 \%)$ & $44(13 \%)$ & $84(24.7 \%)$ \\
& $\begin{array}{l}\text { filmstrip chart, and map } \\
\text { 3. }\end{array}$ & & & \\
4. Adequate swings & Adequate chairs and Tables & $85(25 \%)$ & $127(37.4 \%)$ & $15(4.4 \%)$ & $113(33.2 \%)$ \\
5. & Sick bay & $102(30 \%)$ & $110(32.4 \%)$ & $56(16.5 \%)$ & $72(21.2 \%)$ \\
6. & Adequate beds & $25(7.4 \%)$ & $187(55 \%)$ & $08(2.3 \%)$ & $120(35.3 \%)$ \\
7. & Adequate rooms for resting & $51(15 \%)$ & $161(47.4 \%)$ & $44(13 \%)$ & $84(24.7 \%)$ \\
8. & Adequate rooms for learning & $96(28.2 \%)$ & $116(34.1 \%)$ & $38(11.2 \%)$ & $90(26.5 \%)$ \\
9. & Adequate personnel & $157(46.2 \%)$ & $110(32.4 \%)$ & $44(13 \%)$ & $84(24.7 \%)$ \\
\hline
\end{tabular}

Table 6 above showed that a total of $85(25 \%)$ teachers and $24(7.1 \%)$ ministry workers agreed that there were adequate Toys for children use in the day care centres, while a total of $85(25 \%)$ teachers and $15(4.4 \%)$ ministry workers agreed that there were adequate swings for children use in the day care centres. As regards adequate chairs and tables, a total of $102(30 \%)$ teachers and $56(16.5 \%)$ ministry workers agreed to this statement. A total of $51(15 \%)$ teachers and 44 $(13 \%)$ ministry workers agreed that there were adequate beds for children use in the day care centres, while a total of $154(45.3 \%)$ teachers and $68(20 \%)$ ministry workers agreed that there were adequate personnel for children use in the day care centres. The above showed that the available facilities/equipment and instructional materials for children use in the day care centres were not adequate. This finding contradicts Furnishings \& Equipment Guidelines (1997) that adequate furnishing materials and equipment are important components of good quality child care, which the providers and licensing officers needed.

8.7

Table 7. T-Test of Difference between the Mean Scores in the Adequate Facilities/Equipment and Instructional Materials for Children Use in the Day Care Centres' Used by Location?

\begin{tabular}{llllllll}
\hline Civil servants & n & mean & std & df & t-cal & t-critical & decision \\
\hline Teachers & 212 & 9.234 & 1.353 & 121 & 2.134 & 1.640 & $\mathrm{~S}$ \\
Ministry workers & 128 & 9.228 & 1.331 & & & & \\
\hline
\end{tabular}

\section{$\mathbf{P}<\mathbf{0 . 0 5}$}


The result of the above table 7 reveals that there was a significant difference in the adequate facilities/equipment and instructional materials for children use in the day care centres' by location (teachers and civil servants). This was shown by the $\mathrm{t}$-calculated value (2.134) was greater than the $\mathrm{t}$-critic $(1.640), \mathrm{t}$-cal $=2.134$, $\mathrm{t}$-critic $=1.640, \mathrm{P}<0.05$. This implied that although the civil servants from the two locations identified that some of the facilities/equipment and instructional materials for children use in the day care centres' were not adequate, but the inadequacy was not in the same proportion.

\section{Conclusion}

Very many of the teachers and the ministry workers did not keep their child/children in the crèche. Many civil servants took their children to day care centres for following reasons: they wanted to have time to care for themselves, that they were civil servants, and many teachers wanted to get to their place of work and be efficient, while the ministry workers said that their children needed the company of other children. Some parents still kept their child/children in the hands of Illiterate, Primary six certificate, junior secondary school and senior secondary school certificate holders.

The facilities / equipment and instructional materials/instructions for the use of the children were not adequate.

\section{Recommendations}

Based on the findings of this study; the following recommendations were made towards the improvement of pattern of day caring methods among the civil servants:

- Civil servant mothers should disallow their children from staying with the grandmother, the house girl or place of work.

- Reproductive age civil servants mothers should be educated on the need to employ modern day caring methods such as nursery schools and crèches for their children because these are the only ways to make the child refresh their brain and learn effectively by the three tier of the government.

- The government should provide day care centers for the civil servants so that their children can have sound education from grass root because they are the future of tomorrow.

- The government owned and private day care centers should be licensed and be provided with adequate toys, swings and playing equipment for the children.

- The government owned and private day care centers should also be provided with adequate rooms for learning and resting, adequate personnel, bed, chairs, Tables, and sick bay for the children use.

\section{References}

Adetunji (2002). Nursery and Primary Education. Nigeria, Onigbinde Printing Press.

Caidwell (2001). Day Caring Services. New York: Rhneher Pre 3-4.

Campbell-Barr, V. (2010). The Research, Policy and Practice Triangle in Early Childhood Education and Care. In Parker-Rees, Leeson, Willan and Savage, Early Childhood Studies: an introduction to the study of children's lives and worlds. Exeter: Learning Matters.

Care-pros-and-cons "Daycare vs. Nanny care: The Pros and Cons" Retrieved 21 September 2015 from http://www.pregnancy.org/article/daycare-vs-nanny). Parents With Nannies, Inc

Carr, M. (2012). Learning stories: constructing learner identities in early education. London: Sage.

ChildForum Childcare Information. $\quad$ Retrieved $21 \quad$ Sept. 2015 from http://www.chi1dforum.com/options-a-differences-between-ece-programmes/73-private-childcare-arrangements -making-/your-own-and-what-is-involved.html

Cohn, Jonathan. "The Hell Of American Day Care. (Cover Story).” New Republic 244.6 (2013): 20. MAS Ultra School Edition. Web. 7 Oct. 2013.

Daycare Trust (2010). Childcare costs survey 2010. London: Daycare Trust

Furnishings \& Equipment Guidelines for Licensed Child Care Facilities (1997). Developed by Unit for Child Care Research School of Child and Youth Care University of Victoria and Community Care Facilities Licensing Program Vancouver Island Health Authority Canadian Cataloguing in Publication. 
Iversen, Roberta Rehner \& Annie Laurie Armstrong. (2006). Jobs Aren't Enough. Toward a New Economic Mobility for Low-Income Families. Philadelphia: Temple University Press.

Melhuish, E. (2004). A literature review of the impact of early years provision on young children, with emphasis given to children from disadvantaged background.

MORI (2004). Childcare Quality Survey. London: Daycare Trust.

Read, K. H. (2001). The Nursery School, Relationship's Laboratory. Philadephia: W.B. Company.

Schonpflug, Karin, Feminism, Economics \& Utopia. (2008). Time Travelling Through Paradigms (Oxon/London: Routledge, 2008, pp. 159-160 (author economist, Austrian Ministry of Finance, \& lecturer, Univ. of Vienna), citing Rohrlich, R. \& Elaine Hoffman Baruch, Women in Search of Utopia: Mavericks and Mythmakers (N.Y.: Schocken Books, 1984), and Plato, The Republic (ca. 394 B.C.)

Sylva, K., Melhuis, E., Sammons, P., Siraj-Baltchford, I., \& Taggart, B. (2004). The Effective Provision of Pre-School Education (EPPE) Project: Final report-a longitudinal study funded by the DfES 1997-2004, Sure Start Research Report, SSU/FR/2004/01. Nottingham: DCSF.

U.S. Census Bureau (2008). Who is minding the kids? Child care arrangement Winter 2005. Retrieved 21 september 2015 from www.census .gov/population/www/socdemo/child/ppl-2005.html

Warner, M.E., Kristen Anderson, \& George Haddow. (2007). Putting child care in Picture: Why This Service is a Critical Part of Community Infrastructure Planning, June, 16-19. Retrieved from http://economicdevelopmentandchildcare.org/documents/populations/132.pdf

"The cost of child care" Single mother Guide. Retrieved 6 January 2016 from http://singlemotherguide.com/cost-of-child-care/

http://ww.healthof children.com/D/Day-care.html. (Retrieved 6 January 2016).

https://en.wikipedia.org/wiki/child_care. (Retrieved 28 July 2015).

http://!nannycity.com/checking-nanny-references/ (Retrieved 28 July 2015).

http://singlemotherguide.com/cost-of-child-care/. (Retrieved 28 July 2015).

https://www.careforkids.com.au/child-care-articles/article/19/types-of-child-care.(Retrieved 6 January 2016).

http:www.childforum.com/ options-a-difference-between-ece (Retrieved 21 september 2015).

http:www.yellowpage.ca/what-are-the-different-types-of-daycare. (Retrieved 28 July 2015). 